\title{
Identifikasi Kematangan Cabai Menggunakan Operasi Morfologi (Opening dan Closing) dan Metode Backpropagation
}

\author{
Khairullah, Erwin Dwika Putra* \\ Teknik Informatika, Fakultas Teknik, Universitas Muhammadiyah Bengkulu, \\ Jl. Bali Kota Bengkulu Po.Box 38119 \\ *e-mail: erwindwikap@gmail.com
}

(received: 14 Oktober 2020, revised: 17 November 2020,accepted: 17 Desember 2020)

\begin{abstract}
Abstrak
Identifikasi kualitas buah cabai biasanya masih menggunakan cara visual secara langsung atau sortir secara manual oleh petani, dengan menggunakan sistem ini sering kali terjadi beberapa kesalahan setiap melakukan sortir yang disebabkan oleh petani yang melakukan sortir merasa terlalu lelah. Dengan menggunakan komputasi pengolahan citra digital, untuk melakukan identifikasi pengelompokan buah cabai yang matang dan mentah dapat membantu para petani, Teknik pengelompokan ini akan menggunakan metode pengelompokan berdasarkan warna. Metode pengelompokan tersebut sebelumnya akan dilakukan operasi morfologi pada citra yang telah diambil. Pendekatan operasi morfologi pada penelitian ini adalah Opening and Closing, pada operasi morfologi akan menghilangkan noise dan menebalkan objek dari inputan gambar. Metode Bacpropagatioan akan mengolah data latih sebanyak 10 data latih mendapatkan 6 iterasi perhitungan dan setelah diuji menggunakan data uji hasil yang didapatkan yaitu tingkat pengenalan rata-rat mendapatkan perhitungan sebanyak 7 iterasi metode Bacpropagation. Hasil dari penelitian ini juga dihitung menggunakan Confusion Matrix dimana nilai Precision 90\%, Recall 74\%, dan Accuracy 70\%, maka dapat disimpulkan bahwa Operasi Morfologi dan Metode Backpropagation dapat digunakan untuk mengidentifikasi objek cabai.
\end{abstract}

Kata Kunci: backpropagation, morfologi, identifikasi, opening and closing

\begin{abstract}
Identification of the quality of chili fruit is usually still using a visual way directly or sorting manually by farmers, using this system often occurs several errors, every sorting caused by farmers who do the sorting feel too tired. By using digital image processing computing, to identify the grouping of ripe and raw chili fruits can help farmers, this grouping technique will use a method of grouping based on color. The grouping method will previously perform morphological surgery on the image that has been taken. The morphological operation approach in this study is Opening and Closing, in morphological operations will eliminate noise and thicken objects from image input. Bacpropagatioan method will process training data as much as 10 training data get 6 iterations of calculations and after being tested using the test data obtained results that is the level of introduction of the average rat get a calculation of 7 iterations bacpropagation method. The results of this study were also calculated using Confusion Matrix where precision values of 90\%, Recall 74\%, and Accuracy 70\%, it can be concluded that Morphological Operations and Backpropagation Method can be used to identify chili objects.
\end{abstract}

Keywords: backpropagation, morfologi, identification, opening and closing

\section{Pendahuluan}

Identifikasi buah dalam mencari tingkat kematangan buah yang saat ini dilakukan pada perkebunan dan rumah kaca masih menggunakan cara yang manual. Definisi menggunakan cara yang manual itu sendiri yaitu masih menggunakan pengamatan visual secara langsung terhadap buah yang akan dikelompokkan [1], identifikasi buah terdiri dari dua pengelompokan yaitu buah yang sudah matang dan buah yang masih mentah [1][2]. Identifikasi buah juga dapat menggunakan cara 
komputasi yaitu dengan cara melakukan pengamatan visual secara tidak langsung menggunakan kamera untuk mendapatkan gambar yang selanjutnya akan diolah menjadi sebuah data digital menggunakan komputer[1][3]. Cara ini juga disebut dengan bidang ilmu pengolahan citra digital (Image Processing)[2][4].

Pengolahan citra digital (Image Processing) metode yang dapat digunakan untuk mendapatkan suatu informasi dari sebuah pengolahan gambar, dengan cara memanipulasi gambar menjadi citra digital untuk mendapatkan suatu informasi tertentu [4]. Informasi yang didapatkan pada pengolahan citra digital merupakan pengolahan setiap nilai warna seperti susunan warna RGB, CMY, HSV, HSI dan normalisasi warna [5][6]. Pada penelitian ini bertujuan untuk mengidentifikasi kematangan buah dengan mengelompokkan atau mengklasifikasikan buah matang dan buah mentah. Klasifikasi dipergunakan untuk mengelompokkan objek dengan ketentuan tertentu berdasarkan nilai atribut yang berkaitan dengan objek [7].

Identifikasi kualitas buah cabai biasanya masih menggunakan cara visual secara langsung atau sortir secara manual oleh petani, dengan menggunakan sistem ini sering kali terjadi beberapa kesalahan setiap melakukan sortir yang disebabkan oleh petani yang melakukan sortir merasa terlalu lelah [4]. Dengan menggunakan komputasi pengolahan citra digital, untuk melakukan identifikasi pengelompokan buah cabai yang matang dan mentah dapat membantu para petani, Teknik pengelompokan ini akan menggunakan metode pengelompokan berdasarkan warna.

Metode pengelompokan tersebut sebelumnya akan dilakukan operasi morfologi pada citra yang telah diambil, operasi morfologi merupakan pendekatan topologi dan geometri yang digunakan untuk menganalisis citra mendapatkan nilai ekstraksi struktur dan bentuk geometri [8][9]. Pendekatan operasi morfologi pada penelitian ini adalah Opening and Closing, yang akan menghasilkan nilai ekstraksi warna objek buah cabai pada data latih yang telah dikumpulkan. Data latih tersebut yang nantinya akan diolah oleh metode Backpropagation.

Pada penelitian ini menggunakan metode jaringan syaraf tiruan backpropagation, dengan melihat jenis tingkat warna dari kematangan cabai sering ditemukan perbedaan dan kemiripan [10], dan berdasarkan referensi yang digunakan pada penelitian sebelumnya telah dilakukan dengan objek buat tomat, metode ini dapat menghasilkan nilai peresentase identifikasi kematangan buah tomat sebesar $71,76 \%$. Juga pada penelitian objek buat tomat menggunakan metode ini dapat menghasilkan tiga output yaitu tomat matang $85 \%$, Muda $45 \%$, dan setengah masak $85 \%$ [1].

Selanjutnya penelitian ini untuk mendapatkan nilai tingkat persentase keberhasilan operasi morfologi dan metode jaringan saraf tiruan backpropagation ini akan diukur menggunakan perhitungan confusion matrix, dimana pengukuran ini nantinya akan mendapatkan tiga output yaitu Accuracy, Precision and Recall.

\section{Tinjauan Literatur}

Penelitian identifikasi buah yang pernah dilakukan yaitu menggunakan ekstraksi fitur warna dan sebagai objek penelitian yaitu buah apel. Pada penelitian ini yang dilakukan adalah melakukan Analisis fitur dan ekstraksi fitur warna untuk menghasilkan klasifikasi buah apel, dari hasil identifikasi pengenalan pola Data yang digunakan adalah image buah apel yang terdiri atas 50 buah foto dari 5 kelas apel dengan masing-masing kelompok memiliki 10 buah image. Data citra apel dibagi menjadi 35 data latih dan 15 data uji dan didapatkan hasil tingkat akurasi pengenalan pola sebesar 93,33\% untuk fitur homoginitas,73.33\% untuk bentuk tekstur dan 100\% untuk fitur RGB [7].

Penelitian klasifikasi buah apel juga dikembangkan menggunakan metode pembedaan setiap warna dasar yang didapatkan dari image. Tujuan dari penelitian ini yaitu untuk mengelompokkan beberapa jenis buah apel, dengan metode pemisahan warna HSI dapat mengelompokkan jenis apel berdasarkan warna apel. Hasil dari penelitian ini tingkat akurasi yang didapatkan dari pengelompokan buah apel berdasarkan warna HSI yaitu mencapai tingkat akurasi 70\% [5].

Penelitian yang selanjutnya dikembangkan yaitu metode YCbCR untuk mengelompokkan atau mengklasifikasikan kualitas cabai mentah, setengah matang, dan matang. Pada penelitian ini diolah data uji sebanyak 30 sampel, 10 sampel data image cabai mentah, 10 sampel setengah matang, dan 10 sampel data uji cabai matang. Data testing yang digunakan sebanyak 10 sampel data testing dengan 
mendapatkan nilai tingkat akurasi 96\% tingkat keberhasilan untuk mengelompokkan data berdasarkan data uji sampel [4].

Penelitian yang memfokuskan pada kualitas buah jeruk yang menggunakan perangkat komputerisasi juga telah dilakukan, pada penelitian ini menggunakan algoritma jaringan saraf tiruan metode backpropagation, sebelum menggunakan metode backpropagation pada penelitian ini melakukan tahapan pengenalan warna serta tingkat kedalaman warna yang dihasilkan dari data sampel. Data sampel yang digunakan pada penelitian ini yaitu 200 data sampel data uji dan data testing, hasil dari penelitian ini mendapatkan tingkat akurasi pengenalan kualitas buah jeruk yang baik yaitu sebesar $95.85 \%$ tingkat validasi akurasi [11].

Pengembangan penelitian metode backpropagation telah dikembangkan pada dunia kesehatan [12], dimana pada penelitian ini metode backpropagation digunakan untuk melakukan klasifikasi penyakit demam berdarah. pada penelitian ini menjelaskan bahwa algoritma jaringan saraf tiruan metode backpropagation digunakan untuk melakukan pendekatan mikroskopis untuk mendapatkan informasi dimana informasi tersebut akan dipresentasekan dalam bentuk pola ekstensi neuron. Hasil penelitian ini mendapatkan tingkat akurasi sebesar 74\% klasifikasi [13].

Penelitian metode backpropagation objek buah apel dengan memfokuskan warna merah pada buah apel dengan mengelompokkan 2 klasifikasi yaitu excellent and good ratio. Pada penelitian ini menggunakan tahapan dari awal pengambilan data menggunakan kamera secara real time yang selanjutnya mengambil gambar dengan capture dari hasil perekaman video. Dengan tahapan ini pada penelitian ini menghasilkan tingkat akurasi 95\% klasifikasi buah apel dengan menggunakan fokus warna merah pada buah apel [14].

Setiap penelitian diatas telah menjelaskan bahwa metode backpropagation masih memerlukan data dari proses pra prosessing, pada penelitian ini akan menggunakan data pra prosessing menggunakan operasi morfologi (Opening dan Closing). Berdasarkan penelitian sebelumnya operasi morfologi telah digunakan pada deteksi plat nomor kendaraan, hasil dari penelitian ini dapat mendeteksi plat nomor kendaraan berdasarkan besar dan kecilnya ukuran plat nomor kendaraan menggunakan operasi morfologi [15]. Dengan melihat dari penelitian sebelumnya hasil pra prosessing yang akan digunakan pada penelitian ini dapat membantu proses komputasi identifikasi cabai matang dan mentah menggunakan metode backpropagation.

\section{Metode Penelitian}

Tahapan metode penelitian pada penelitian ini adalah pengumpulan data, pengolahan data, analisis data, pengukuran hasil, dapat terlihat pada gambar 1 .

Pada gambar 1 penelitian ini diawali dengan pengumpulan data, pada tahapan ini dibagi menjadi tiga tahapan yaitu Observasi, Wawancara, dan Studi Pustaka. Tahapan observasi diawali dengan mengumpulkan data langsung kepada petani cabai dengan melihat langsung perkebunan cabai. Tahapan wawancara diawali dengan mewawancarai petani cabai yang ada pada lokasi perkebunan cabai, mulai dari bertanya kualitas cabai yang baik, sampai dengan proses sortir untuk kualitas cabai matang dan cabai mentah.

Dilanjutkan dengan mengumpulkan data pustaka sebagai referensi yang dapat digunakan untuk mendukung data penelitian dan mendapatkan hasil review pustaka yang digunakan. Berdasarkan referensi pustaka yang dikumpulkan didapatkanlah kelebihan dan kekurangan masing-masing metode pada pengolahan citra digital dengan demikian pada penelitian ini diusulkan menggunakan jaringan saraf tiruan metode backpropagation dan operasi morfologi sebagai tahapan pra prosessing untuk mendapatkan kesimpulan penelitian. 


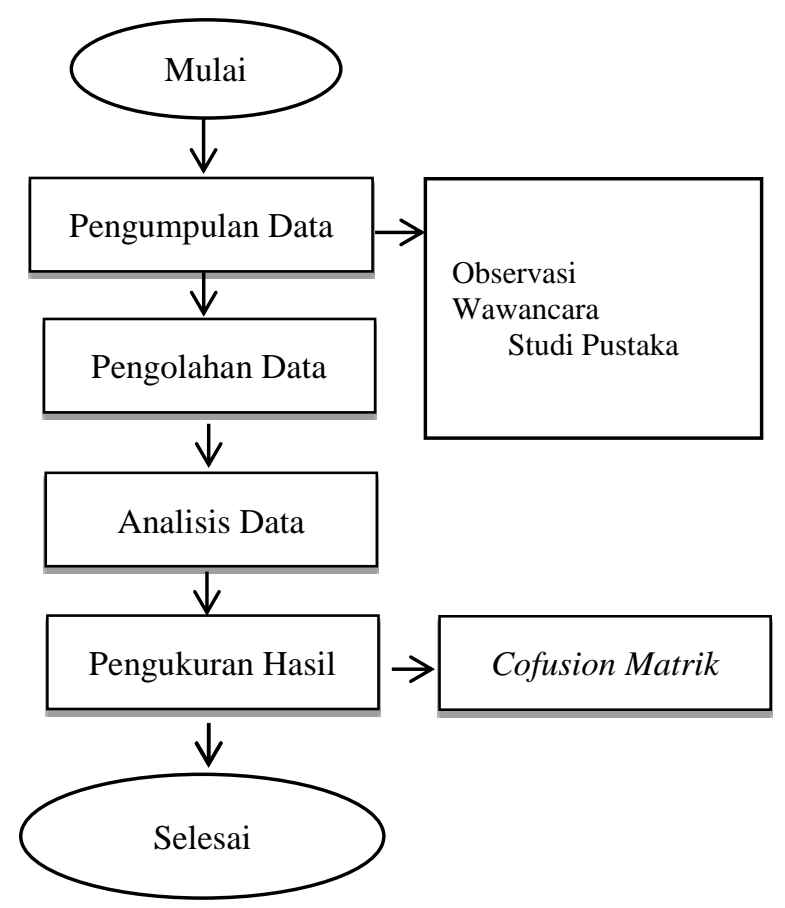

Gambar 1. Tahapan Metode Penelitian

\section{Hasil dan Pembahasan}

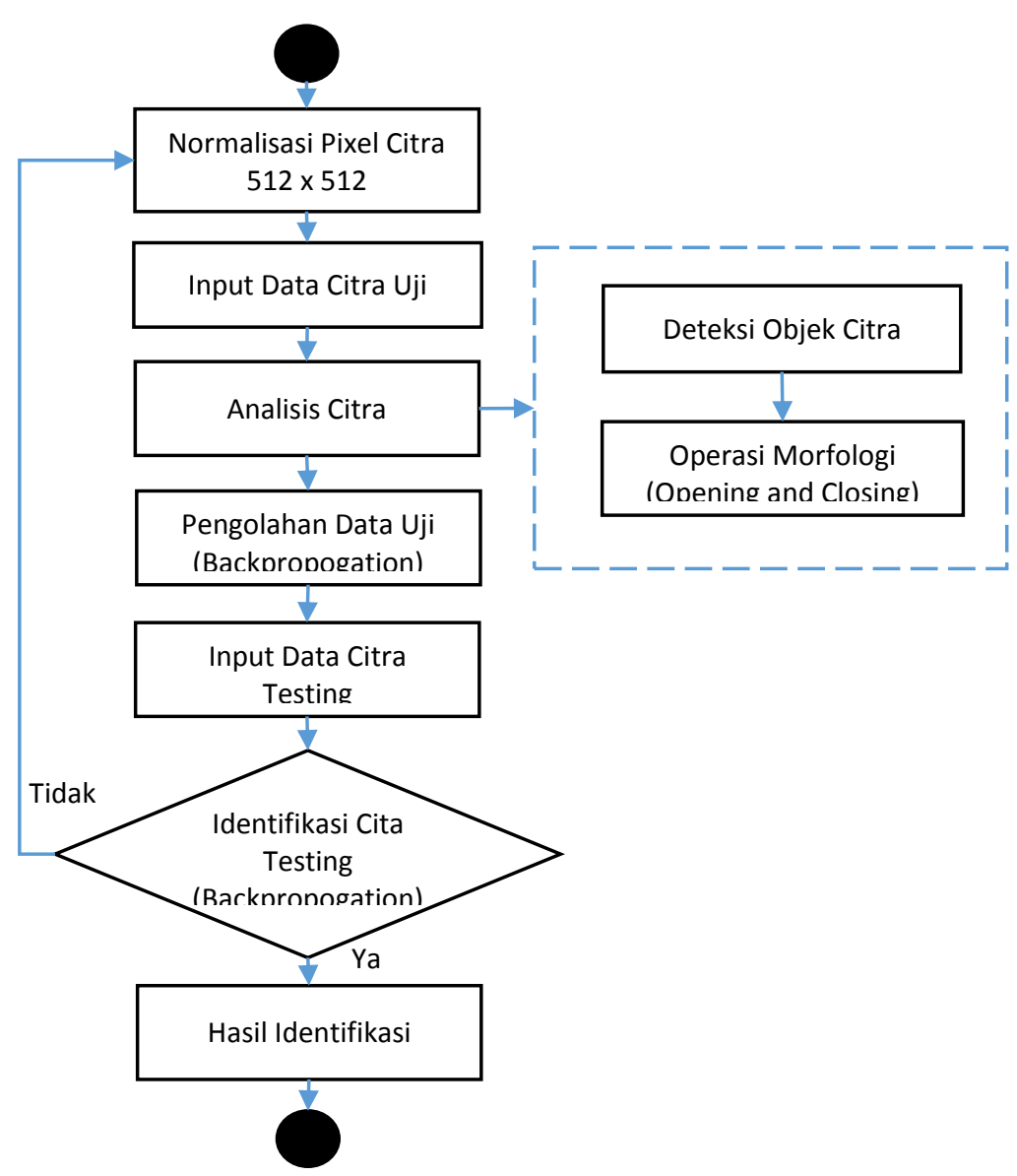

Gambar 2. Alur Komputasi 
Data citra digital yang digunakan pada penelitian ini berjumlah 50 citra yang terbagi menjadi 10 data latih cabai matang, 10 data latih cabai mentah, 15 data uji cabai matang, 15 data uji cabai mentah. Tahapan komputasi yang dilaksanakan pada penelitian ini mengacu pada alur penelitian yang telah disesuaikan, seperti gambar 2.

Tahap pertama setelah mendapatkan data latih dan data uji maka selanjutnya data tersebut akan dinormalisasi dengan ukuran pixel yang ditentukan yaitu 512 x 512 pixel, proses normalisasi dilakukan agar mempermudah peneliti dalam mengolah citra dan mempermudah kinerja komputasi untuk mengolah data training (data latih) [16]. Proses normalisasi juga dilakukan terhadap data uji, dengan proses dan tujuan yang sama seperti data latih.
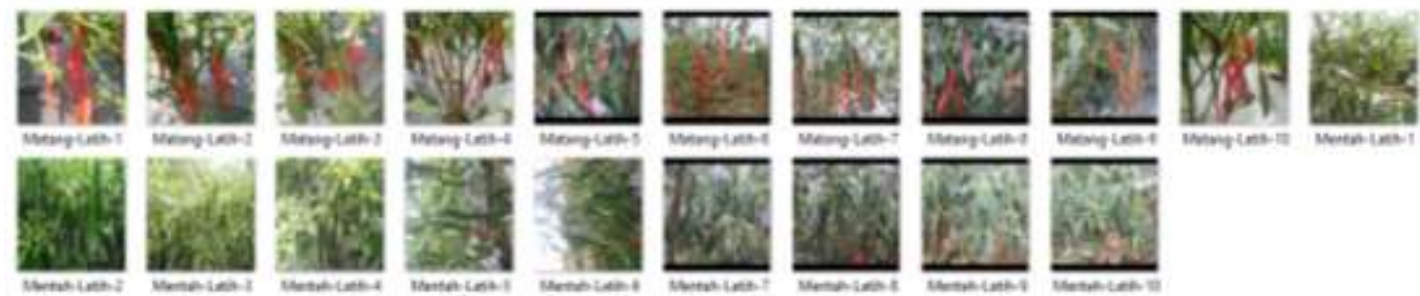

Gambar 3. Data Latih (Training) Telah Normalisasi
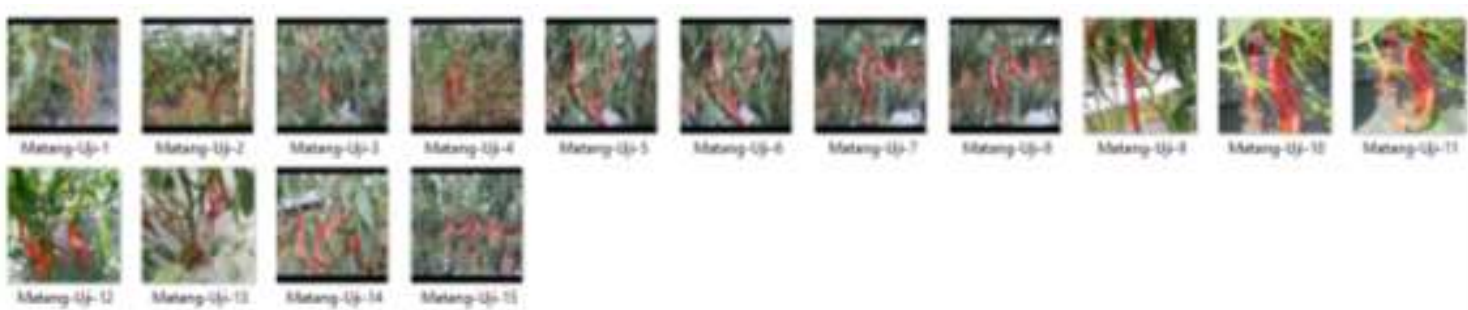

Gambar 4. Data Uji (Testing) Cabai Matang Telah Normalisasi
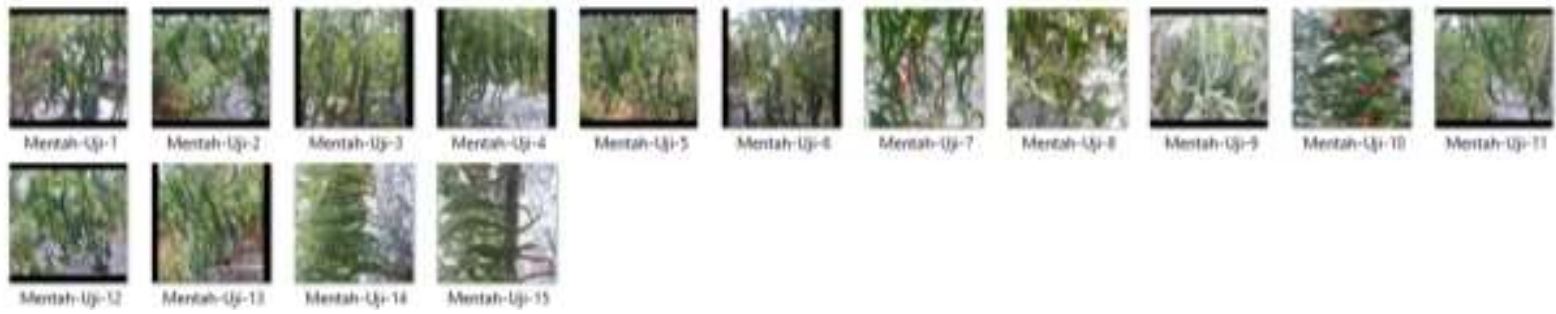

Gambar 5. Data Uji (Testing) Cabai Mentah Telah Normalisasi

Setelah data uji dan data testing di normalisasi, selanjutnya data uji akan diolah pada pemrograman komputasi menggunakan MATLAB. Tahapan ini adalah tahapan analisis citra uji yaitu dengan mendapatkan ekstraksi fitur warna dari setiap citra, hasil ekstraksi warna tersebut akan mendapatkan perbedaan antara foreground dan background pada citra. Objek yang terdapat pada citra akan terdeteksi pada foreground, hasil deteksi ini akan dilanjutkan dengan menggunakan operasi morfologi opening dan closing berdasarkan persamaan berikut :

$A \cdot B=(A \oplus B) \ominus B$

$A \circ B=(A \ominus B) \oplus B$

Fungsi operasi opening dan closing ini melakukan proses operasi erosi dan dilasi untuk menghilangkan noise kecil yang terdapat pada citra bineri yang akan diolah, dengan hasil contoh citra seperti gambar 6 berikut: 

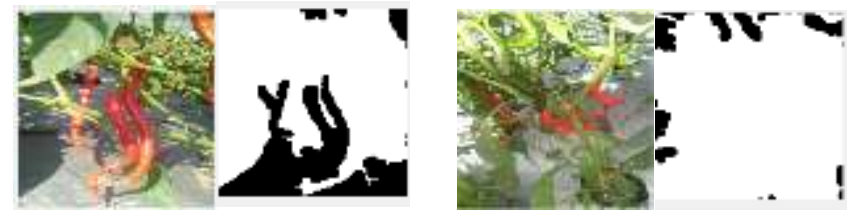

Gambar 6. Operasi Closing

Pada Gambar 6 di atas operasi closing menggunakan area operasi disk dengan tingkat deteksi thresholding (ambang batas) sebanyak 10 pixel dari pixel original seperti pada contoh pixel yang ditunjukkan pada Gambar 7 di bawah ini:

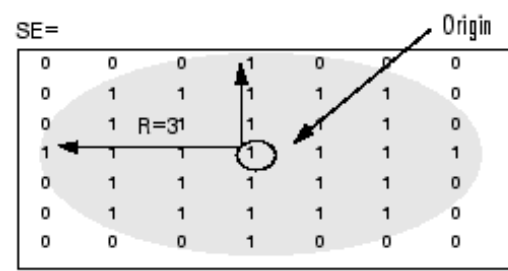

\section{Gambar 7. Operasi Streel ('Disk') 10 Pixel Tetangga}

Hasil pada operasi closing akan dilanjutkan dengan operasi opening untuk mendapatkan objek citra pada proses binerisasi, dengan menggunakan penghapusan pixel yang dianggap bukan merupakan objek yang diinginkan. Proses operasi opening dan closing dilakukan secara berulang sebanyak citra uji yang digunakan pada penelitian ini, yang selanjutnya hasil dari citra operasi opening dan closing di olah menggunakan persamaan jaringan saraf tiruan metode Backpropagation. Dengan proses komputasi sebagaimana Gambar 8 berikut:

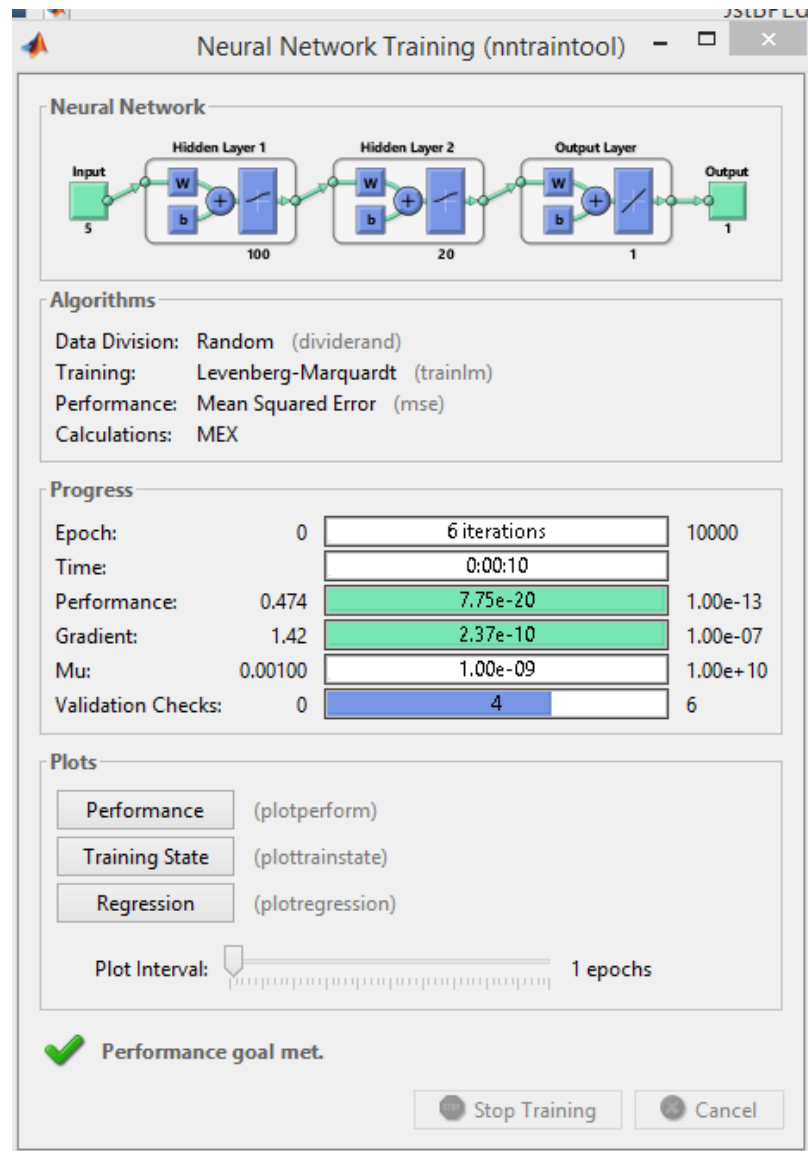

Gambar 8. Proses Metode Backpropagation 
Dari proses komputasi diatas dapat terlihat bahwa dari total data uji 30 citra, terdapat 6 iterasi yang dilakukan dalam perhitungan proses pengenalan data uji oleh metode backpropagation. Dengan hasil perhitungan matrix seperti dibawah ini:

akurasi $=65$

Input $=$ Columns 1 through 10

$\begin{array}{llllllllll}0.1492 & 0.3521 & 0.6289 & 0.3062 & 0.3565 & 0.6521 & 0.4166 & 0.6317 & 0.8101 & 0.6837 \\ 0.5884 & 0.5911 & 0.1799 & 0.2101 & 0.4682 & 0.3039 & 0.4618 & 0.2096 & 0.0475 & 0.2686 \\ 0.5698 & 0.4718 & 0.4555 & 0.5425 & 0.4581 & 0.4059 & 0.4941 & 0.5478 & 0.3948 & 0.4636 \\ 0.5527 & 0.4951 & 0.4969 & 0.5694 & 0.4788 & 0.4289 & 0.4715 & 0.5588 & 0.4086 & 0.4736 \\ 0.4262 & 0.3737 & 0.3651 & 0.4066 & 0.3625 & 0.3662 & 0.3697 & 0.4837 & 0.3565 & 0.4087\end{array}$

Columns 11 through 20

$\begin{array}{llllllllll}0.4971 & 0.6633 & 0.7896 & 0.4890 & 0.5522 & 0.6755 & 0.3612 & 0.7055 & 0.6998 & 0.3698 \\ 0.3277 & 0.1309 & 0.0842 & 0.4789 & 0.2026 & 0.1554 & 0.5830 & 0.1176 & 0.0872 & 0.4035 \\ 0.5113 & 0.5438 & 0.2970 & 0.5350 & 0.4907 & 0.4802 & 0.5149 & 0.4266 & 0.3802 & 0.5344 \\ 0.5427 & 0.5883 & 0.4196 & 0.5974 & 0.5543 & 0.5251 & 0.5469 & 0.4630 & 0.4065 & 0.5677 \\ 0.4071 & 0.4951 & 0.2182 & 0.3957 & 0.3876 & 0.4249 & 0.4751 & 0.4004 & 0.3455 & 0.4813\end{array}$

Target $=$

Columns 1 through 17

$\begin{array}{lllllllllllllllll}1 & 1 & 1 & 1 & 1 & 1 & 1 & 1 & 1 & 1 & 2 & 2 & 2 & 2 & 2 & 2 & 2\end{array}$

Columns 18 through 20

$$
222
$$

Output =

Columns 1 through 17

$\begin{array}{lllllllllllllllll}1 & 1 & 2 & 1 & 1 & 1 & 1 & 1 & 2 & 2 & 1 & 2 & 1 & 2 & 1 & 2 & 2\end{array}$

Columns 18 through 20

$2 \quad 2 \quad 1$

Selanjutnya akan melakukan proses input data uji, untuk menguji apakah identifikasi setiap citra objek dapat dikenali sebagai data cabai matang atau cabai mentah, hasil identifikasi ini dapat dilihat dari hasil prototipe program pada Gambar 9 di bawah ini:

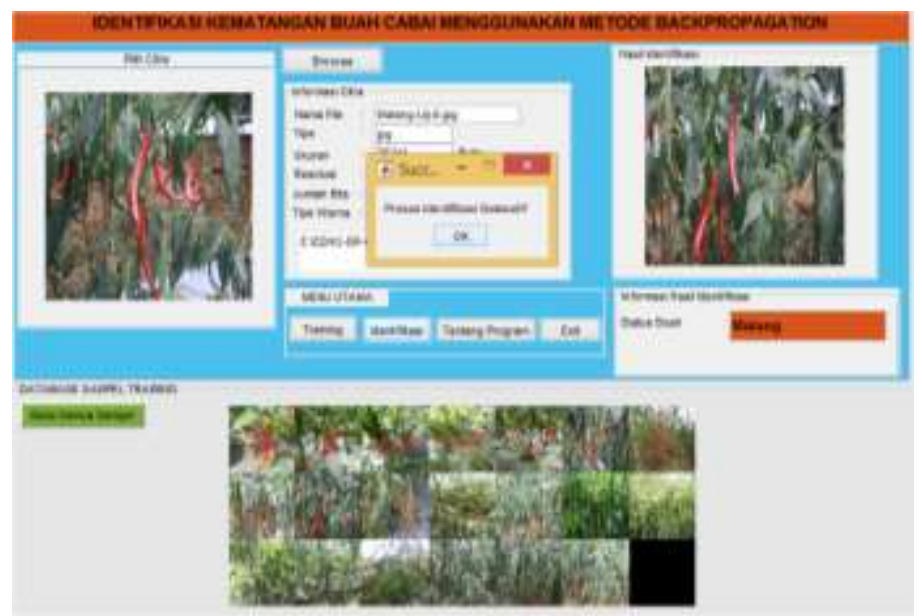

Gambar 9. Hasil identifikasi (Prototipe Program)

Dari keseluruhan data latih dan data uji yang digunakan, hasil identifikasi ini akan dihitung tingkat akurasi, presisi dan recall. Untuk mendapatkan 3 variable tersebut digunakan rumus perhitungan confusion matrix seperti persamaan (3) di bawah ini:

Precision $=\frac{T P(\text { True Positif })}{T P(\text { True Positif })+F P(\text { False Positif })}$ 
Recall $=\frac{T P(\text { True Positif })}{\text { TP(True Positif })+F N(\text { False Negatif })}$

Accuracy $=\frac{T P(\text { True Positif })+T N(\text { True Negatif })}{T P+T N+F P(\text { False Positif })+F N}$

Confusion Matrix mempunyai rules untuk mendapatkan perhitungan diatas, dimana rule tersebut dapat dilihat pada Tabel 1 di bawah ini:

Tabel 1. Rule Confusion Matrix

\begin{tabular}{|c|c|c|}
\hline \multirow{2}{*}{$\begin{array}{c}\text { Nilai } \\
\text { Prediksi }\end{array}$} & TRUE & Nilai Sebenarnya \\
\cline { 2 - 3 } True & $\begin{array}{c}\text { TP (true positive) Hanya } \\
\text { Yang benar/relevan }\end{array}$ & $\begin{array}{c}\text { FP (False Positive) } \\
\text { Hasil yang tidak diharapkan /tidak relevan }\end{array}$ \\
\hline False & $\begin{array}{c}\text { FN (False Negative) } \\
\text { Hasil yang hilang/negative } \\
\text { ditemukan }\end{array}$ & $\begin{array}{c}\text { TN (True Negative) Tidak ada hasil yang } \\
\text { benar }\end{array}$ \\
\hline
\end{tabular}

Berdasarkan rumus dan rule confusion matrix diatas maka pada penelitian ini menghasilkan nilai setiap hasil dari data uji seperti pada Tabel 2 di bawah ini:

Tabel 2. Hasil Pengujian

\begin{tabular}{|c|c|c|c|c|c|}
\hline No & Nama Citra & TP & FP & FN & TN \\
\hline 1. & Matang Uji 1 & $\sqrt{ }$ & & & \\
\hline 2. & Matang Uji 2 & $\sqrt{ }$ & & & \\
\hline 3. & Matang Uji 3 & & & $\sqrt{ }$ & \\
\hline 4. & Matang Uji 4 & $\sqrt{ }$ & & & \\
\hline 5. & Matang Uji 5 & $\sqrt{ }$ & & & \\
\hline 6. & Matang Uji 6 & $\sqrt{ }$ & & & \\
\hline 7. & Matang Uji 7 & & $\sqrt{ }$ & & \\
\hline 8. & Matang Uji 8 & & $\sqrt{ }$ & & \\
\hline 9. & Matang Uji 9 & $\sqrt{ }$ & & & \\
\hline 10. & Matang Uji 10 & $\sqrt{ }$ & & & \\
\hline 11. & Matang Uji 11 & $\sqrt{ }$ & & & \\
\hline 12. & Matang Uji 12 & $\sqrt{ }$ & & & \\
\hline 13. & Matang Uji 13 & & & $\sqrt{ }$ & \\
\hline 14. & Matang Uji 14 & & & $\sqrt{ }$ & \\
\hline 15. & Matang Uji 15 & $\sqrt{ }$ & & & \\
\hline 16. & Mentah Uji 1 & & & $\sqrt{ }$ & \\
\hline 17. & Mentah Uji 2 & $\sqrt{ }$ & & & \\
\hline 18. & Mentah Uji 3 & $\sqrt{ }$ & & & \\
\hline 19. & Mentah Uji 4 & $\sqrt{ }$ & & & \\
\hline 20. & Mentah Uji 5 & & & $\sqrt{ }$ & \\
\hline 21. & Mentah Uji 6 & $\sqrt{ }$ & & & \\
\hline 22. & Mentah Uji 7 & & & & $\sqrt{ }$ \\
\hline 23. & Mentah Uji 8 & $\sqrt{ }$ & & & \\
\hline 24. & Mentah Uji 9 & & & $\sqrt{ }$ & \\
\hline 25. & Mentah Uji 10 & & & $\sqrt{ }$ & \\
\hline 26. & Mentah Uji 11 & $\sqrt{ }$ & & & \\
\hline 27. & Mentah Uji 12 & $\sqrt{ }$ & & & \\
\hline 28. & Mentah Uji 13 & $\sqrt{ }$ & & & \\
\hline 29. & Mentah Uji 14 & $\sqrt{ }$ & & & \\
\hline 30. & Mentah Uji 15 & $\sqrt{ }$ & & & \\
\hline
\end{tabular}


Berdasarkan table diatas maka dapat dihitung nilai tingkat presisi, recall dan akurasi identifikasi cabai menggunakan operasi morfologi (Opening and Closing) dan metode backpropagation, seperti di bawah ini:

$$
\begin{aligned}
\text { Precision } & =\frac{20}{20+2}=0.90 \\
& =0.90 * 100=90 \% \\
\text { Recall } & =\frac{20}{20+7}=0.74 \\
= & 0.74 * 100=74 \% \\
\text { Accuracy } & =\frac{20+1}{20+1+2+7}=0.7 \\
& =0.7 * 100=70 \%
\end{aligned}
$$

Hasil penelitian identifikasi buah cabai menggunakan Operasi Morfologi (Opening dan Closing) dan metode Backpropagatioan mendapatkan tingkat keberhasilan yang memuaskan dengan tingkat keberhasilan lebih dari $50 \%$ persentase.

a. Precision = tingkat ketepatan antara informasi yang diminta oleh user dengan jawaban yang diberikan oleh system adalah sebesar $90 \%$.

b. Recall = tingkat keberhasilan system dalam menemukan kembali sebuah informasi yang telah diberikan adalah sebesar $74 \%$.

c. Accuracy $=$ tingkat keberhasilan antara nilai prediksi dengan nilai yang aktual yang diberikan oleh system adalah $70 \%$.

\section{Kesimpulan}

Pada penelitian ini dapat ditarik beberapa kesimpulan yaitu Operasi Morfologi dan Metode Backpropagation dapat digunakan untuk mengidentifikasi objek cabai, dengan melihat hasil dari pengujian menggunakan Confusion matrix, Precision sebesar 90\%, Recall 74\%, dan Tingkat Akurasi 70\%. Pada penelitian ini juga dapat kami simpulkan bahwa Bentuk kualitas citra dan ukuran pixel dari sebuah citra dalam pengujian sangatlah berpengaruh pada proses deteksi testing dan uji data. Dan juga faktor pencahayaan sangat mempengaruhi dalam pengambilan citra, karena bayangan yang di pantulkan mempengaruhi hasil warna dari cabai.

\section{Referensi}

[1] D. Deswari, Hendrick, and Derisma, "Identifikasi Kematangan Buah Tomat Menggunakan Metoda Backpropagation," 2016.

[2] R. Kastaman and A. Wasi, "Analisis Kinerja Perangkat Lunak Pengolah Citra dengan Menggunakan Beberapa Metode Klasifikasi untuk Menentukan Kualitas Buah Manggis," Pros. Seminar Nasional Himpun. Inform. Pertan. Indonesia., pp. 978-979, 2009.

[3] M. H. Noor and M. Hariadi, "Image Cluster Berdasarkan Warna untuk Identifikasi Kematangan Buah Tomat dengan Metode Valley Tracing," Seminar Nasional Informatika 2009,pp.1524,2009,[Online].Available: http://Jurnal.Upnyk.Ac.Id/Index.Php/Semnasif/Article/View/798.

[4] A. Indra, Dwi and Murinto, "Aplikasi Pengolahan Citra Mendeteksi Kualitas Cabai Berdasarkan Tingkat Kematangan Menggunakan Transformasi Warna YCbCr," J. Sarj. Tek. Inform., Vol. 3, No. 1, pp. 283-293, 2015, doi: 10.12928/Jstie.V3i1.3036.

[5] F. Guo and Q. Cao, "Study on Color Image Processing Based Intelligent Fruit Sorting System," Proc. World Congr. Intell. Control Autom., Vol. 6, pp. 4802-4805, 2004, doi: 10.1109/Wcica.2004.1343622. 
[6] R. D. Kusumanto, A. Tompunu, Novi, and W. Pambudi, Setyo, "Klasifikasi Warna Menggunakan Pengolahan Model Warna HSV,"[Online]. Available: http://elektro.pnj.ac.id/upload/artikel/files/04_edit\%26layout_rdkusmanto_jee sept2011_klasifikasi warna.pdf.

[7] A. Qur'ania, L. Karlitasar, and S. Maryana, "Analisis Tekstur dan Ekstraksi Fitur Warna untuk Klasifikasi Apel Berbasis Citra," Lokakarya Komputasi dalam Sains dan Teknol. Nukl., pp. 296-304, 2012, [Online]. Available: http://digilib.batan.go.id/e-prosiding/file prosiding/informatika/lkstn/lkstn2012/arie-q2012.pdf.

[8] A. Susanto, "Matematika Citra Digital untuk Ekstraksi Area Plat Nomor," J. Pseudocode, Vol. Vi, No. 1, pp. 49-57, 2019.

[9] P. Pandya and M. Singh, "Morphology Based Approach to Recognize Number Plates in India," Int. J. Soft Comput. Eng., Vol. 1, No. 3, pp. 107-112, 2011.

[10] N. T. Anggraeni and A. Fadlil, "Sistem Identifikasi Citra Jenis Cabai (Capsicum Annum L.) Menggunakan Metode Klasifikasi City Block Distance," Sarj. Tek. Inform., Vol. 1, No. 2, pp. 409-418, 2013, doi: 10.12928/Jstie.V1i2.2265.

[11] Z. Arham, "Evaluasi Mutu Jeruk Nipis ( Citrus Aurantifolia Swingle ) dengan Pengolahan Citra Digital dan Jaringan Syaraf Tiruan,” pp. 81-88, 2004.

[12] F. Amato, A. López, E. M. Peña-Méndez, P. Vaňhara, A. Hampl, and J. Havel, "Artificial Neural Networks in Medical Diagnosis," J. Appl. Biomed., Vol. 11, No. 2, pp. 47-58, 2013, doi: 10.2478/V10136-012-0031-X.

[13] W. Widodo, A. Rachman, and R. Amelia, "Jaringan Syaraf Tiruan Prediksi Penyakit Demam Berdarah dengan Menggunakan Metode Backpropagation," J. Iptek, Vol. 18, No. 1, pp. 64-70, 2014.

[14] K. Nakano, "Application of Neural Networks to the Color Grading of Apples," Comput. Electron. Agric., Vol. 18, No. 2-3, pp. 105-116, 1997, doi: 10.1016/S0168-1699(97)00023-9.

[15] D. A. Priandini, J. Nangi, M. Muchtar, and J. Y. Sari, "Deteksi Area Plat Mobil Menggunakan Operasi Morfologi Citra," Semin. Nas. Teknol. Terap. Berbas. Kearifan Lokal, pp. 294-302, 2018.

[16] D. Abdullah and E. D. Putra, "Komparasi Metode Otsu Dengan Metode Fuzzy Cmeans pada Hasil Segmentasi Identifikasi Karakter Plat Nomor Kendaraan Indonesia," Telematik, Vol. 6, No. 4, pp. 1475-1484, 2013. 